\title{
Vitamin C: optimal dosages, supplementation and use in disease prevention
}

\author{
Callen Pacier and Danik M. Martirosyan
}

Functional Food Center/Functional Food Institute, Dallas, TX 75252, USA

Corresponding Author: Danik Martirosyan, PhD, Functional Food Center/Functional Food Institute, 7575 Frankford Rd, Suite 3527, Dallas, TX, 75252, USA

Submission date: February 4, 2015; Acceptance date: March 5, 2015, Publication date: March 7 , 2015

\section{ABSTRACT:}

The importance of vitamin $\mathrm{C}$ as a way to prevent scurvy has been known for centuries. More recent research on vitamin $\mathrm{C}$ has expanded beyond scurvy prevention, providing promising evidence for additional health benefits and clinical applications. This review of scientific literature will evaluate many aspects of vitamin $\mathrm{C}$ including deficient versus optimal blood plasma levels, adequate daily amounts necessary to maintain ideal levels, and the safety of higher doses. It will also focus on the importance of vitamin $\mathrm{C}$ as a powerful bioactive compound, and its utilization in the prevention and management of different chronic diseases. This review is necessary to express the importance of alternative healthcare methods in both preventative and clinical care. Vitamin $\mathrm{C}$ was chosen as a representative of this concept due to its powerful antioxidant capacity, incredibly important physiological implications, and very minimal chance of side-effects. This review focuses on studies involving human participants that address how vitamin $\mathrm{C}$ is important for our health.

Keywords: Ascorbic acid, deficiency, disease, dose, health, supplementation, vitamin C

\section{INTRODUCTION:}

Vitamin $\mathrm{C}$ was first identified in fruits (citrus), vegetables and adrenal glands as hexuronic acid in the 1920s by Albert Szent-Györgyi, a Hungarian biochemist. With the help of an American physician named Joseph Svibely, Szent-Györgyi was able to identify that hexuronic acid was vitamin $\mathrm{C}$ through scurvy research on guinea pigs. It was later named ascorbic acid (meaning "without scurvy" from Latin) by Szent-Györgyi and Norman Haworth, a scientist who also studied vitamin $\mathrm{C}[1]$.

Vitamin $\mathrm{C}$ is a crucial component to human health. This particular vitamin is water soluble (causing quick elimination and preventing storage) and cannot be synthesized by humans; therefore, it is essential that vitamin $\mathrm{C}$ be incorporated into our diet [2]. The particular mechanism that prevents synthesis is the absence of gulonolactone oxidase (GLO) [3], which is necessary to catalyze the enzyme L-gulono-1,4-lactone oxidase, the final step in the biosynthetic pathway of vitamin $\mathrm{C}$ [4]. There are numerous reasons why vitamin $\mathrm{C}$ is important to our health, 
but many involve its aspect as essential factor in the synthesis of collagen, carnitine and norepinephrine [5].

The two main components of vitamin $\mathrm{C}$ are ascorbate and dehydroascorbic acid (DHA) [3]. The transport of ascorbate through the human body involves two sodium-dependent vitamin $\mathrm{C}$ transporters (SVCT): SVCT1 and SVCT2 [6]. The majority of ascorbate is transported by SVCT1 in epithelial cells (e.g. intestine, kidney and liver), and the remaining is transported by SVCT2 in specialized cells (e.g. brain and eye) [7]. DHA (the oxidized form of ascorbate) is transported in the human body through 2 glucose transporters (GLUT): GLUT1 and GLUT3 [6] (a third transporter, GLUT 4, is used only for insulin-sensitive tissues [8]). Once DHA has been transported inside the cell by a GLUT, it is reduced back to ascorbate [6]. The distribution and homeostasis of vitamin $\mathrm{C}$ in the human body is regulated by the SVCTs, GLUTs, facilitated diffusion through channels and exocytosis in secretory vesicles [9]. The main concentrations of vitamin $\mathrm{C}$ are located in brain and adrenal cells.

\section{RETRIEVAL OF PUBLISHED STUDIES:}

A systematic review of published studies concerning the importance of vitamin $\mathrm{C}$ for our health was conducted electronically utilizing PubMed® and Google Scholar. Both review and research papers were included. Eligible articles provided reasonable, scientific evidence on the positive benefits of vitamin $\mathrm{C}$ for human health. Articles not available in English were excluded. Keywords for the search included: addict, antioxidant, ascorbic acid, content, cooking, deficiency, disease, dose, elderly, health, history, intake, iron, IV, oral, oxidant, physiological, plasma, pregnant, preparation, prevention, research, risk, safety, scurvy, storage, supplement, symptoms, treatment, and vitamin $\mathrm{C}$.

\section{VITAMIN C AS AN ANTIOXIDANT:}

The importance of vitamin $\mathrm{C}$ stems from its powerful antioxidant capacity. The term antioxidant has been defined as, "any substance that, when present at low concentrations compared to those of an oxidisable substrate, significantly delays or prevents oxidation of that substrate" [10]. Out of the three different antioxidant defense systems, vitamin $\mathrm{C}$ is classified as a chain breaking antioxidant; specifically, an aqueous phase chain breaking antioxidant [11]. As an antioxidant, vitamin $\mathrm{C}$ protects low-density lipoproteins (LDLs) from being oxidized, decreases damaging oxidation in the stomach, and facilitates the absorption of iron [8].

In one study examining the chemical composition of broccoli and cauliflower, vitamin $\mathrm{C}$ was shown to have the highest positive correlation of phytochemicals (phenol, flavonoid and glucosinolate), and the second highest antioxidant activity (only 9.5\% lower than total phenol) [12]. In another study highlighting the antioxidant capacity of jujube fruits, vitamin $\mathrm{C}$ showed the highest correlation coefficient in the 2,2'-azinobis (3-ethylbenzothiazoline-6) sulfonic acid (ABTS) scavenging method (which establishes antioxidant activity) [13].

\section{WHY VITAMIN C IS SO IMPORTANT TO HEALTH:}

Vitamin $\mathrm{C}$ is crucial to our overall health and wellbeing. It should be considered a functional food ingredient, as it is an important bioactive compound with antioxidant properties. A functional food is defined as "natural or processed foods that contain known or unknown 
biologically active compounds; which, in defined amounts, provide a clinically proven and documented health benefit for the prevention, management, or treatment of chronic disease" [14]. Those health benefits are numerous, and will be discussed further in a later section. One of its most important aspects involves its role in cognitive functions, due to its high concentration in the brain [15]. This affects us in different ways throughout our life. Concerning our early years, there is animal-model data to suggest that vitamin $\mathrm{C}$ deficiency in newborns could result in impaired spatial memory due to decreased neurons ( 30\% loss) in the hippocampus [16]. As we get older, the importance of an adequate amount of daily vitamin $\mathrm{C}$ over a lifetime could help prevent certain degenerative diseases. For example, vitamin $\mathrm{C}$ is a main defense against dopamine auto toxicity, a major component of Parkinson's disease [17].

\section{Physiological Role of Vitamin C}

In a general sense, vitamin $\mathrm{C}$ acts as a cofactor and reduces certain enzymes by providing them with electrons, due to its chemical structure [8]. Those enzymes can react with biomolecules known as lipids, proteins and DNA, and cause harm. In order to help prevent that, vitamin $\mathrm{C}$ reduces oxygen species when lipid peroxidation is formed, reduces radical inhibitors in protein oxidation, and prevents nitrosamine formation to reduce DNA damage [18].

The role of vitamin $\mathrm{C}$ in health could be related to its recycling ability in the presence of microorganisms [19]. When microorganisms are present, the amount of vitamin $C$ in neutrophils is 30 times higher than in neutrophils that do not have microorganisms [19]. This is important due to the ability of vitamin $\mathrm{C}$ to provide oxidant protection by scavenging excessive reactive oxygen species (ROS), which cause oxidant damage [19-20]. When more vitamin C is produced due to recycling, the ability to protect the body against damage is increased.

Another reason vitamin $\mathrm{C}$ is important is its ability to facilitate proper iron levels. In one comparison study, individuals who consumed $247 \mathrm{mg}$ of vitamin $\mathrm{C}$ daily had $35 \%$ higher iron absorption levels than those who consumed $51 \mathrm{mg}$ of vitamin $\mathrm{C}$ daily [21].

\section{VITAMIN C DEFICIENCY - INDIVIDUALS AT RISK:}

One reason for this review is the high prevalence of vitamin $\mathrm{C}$ deficient individuals. There is a strong correlation that individuals who smoke tobacco are at risk to be deficient in vitamin $\mathrm{C}$ [22]. This is shown by the United States Department of Agriculture (USDA), who specifically indicate on their Recommended Dietary Allowances (RDA) that smokers require an additional $35 \mathrm{mg}$ of vitamin $\mathrm{C}$ daily to maintain adequate levels [23]. One reason for this association is that smokers tend to consume a less healthy diet (specifically less fruits and vegetables) [24], leading to a $16 \%$ decrease in vitamin $\mathrm{C}$ intake [25]. Another reason is that cigarette smoke causes vitamin $\mathrm{C}$ to deplete at a much faster rate in order to compensate for the oxidative stress [25]. In one study conducted, ascorbate was completely depleted from human plasma after six puffs of cigarette smoke [26].

There is also an association between lower-income households and vitamin $\mathrm{C}$ deficiency. In the United Kingdom, a study was conducted on the $15 \%$ lowest income households to determine plasma vitamin $\mathrm{C}$ levels [27]. The results indicated that $26 \%$ of men and $16 \%$ of women were vitamin $\mathrm{C}$ deficient $(<11 \mu \mathrm{mol})$, and $21 \%$ of men and $18 \%$ of women had depleted vitamin $\mathrm{C}$ levels $(11-28 \mu \mathrm{mol})$ [27]. A main reason for this is that households with lower socioeconomic 
status tend to consume less fruits and vegetables, an essential source of vitamin C. In one study, it was shown that $53 \%$ of low-income households spend less than $\$ 1.00$ a week on fresh fruit and vegetables [28].

Individuals who have more stressful lives (thereby creating more oxidative damage) are at risk for low vitamin $\mathrm{C}$ levels. Vitamin $\mathrm{C}$ decreases more quickly with increased oxidative stress, so higher intakes can help to better manage the increased emotional/physical pressure. It has been shown that helicopter pilots have a more stressful job than non-flight staff based on serum levels of stress indicators, with 21.1\% higher malondialdehyde (MDA), 21.7\% higher superoxide dismutase (SOD), and 25.1\% higher total antioxidant capacity (TAC) [29]. There are also issues of oxidative stress that are a result of a worker's environment, and not necessarily the job itself. Workers who have been exposed to lead ( $73 \mu \mathrm{g}$ of lead/dl of blood) compared to those who haven't $(6.7 \mu \mathrm{g}$ of lead/dl) show a $46.2 \%$ higher thiobarbituric acid reactive species concentration (TBARS (nmol MDA/ml PG)), 60.9\% higher SOD, 70.3\% higher chloramphenicol acetyltransferase (CAT) activity, and a 40\% higher TAC [30]. When these lead-exposed workers were given daily oral $1 \mathrm{~g}$ vitamin $\mathrm{C}$ supplements (in addition to $400 \mathrm{IU}$ vitamin $\mathrm{E}$ ) for one year, their TBARS decreased by $46.2 \%$, TAC decreased by $36.4 \%$, CAT decreased by $59.5 \%$, and SOD decreased by $48.5 \%$, bringing them back down to levels of their non-lead exposed workers [30].

Elderly individuals are at risk for malnutrition from multiple factors such as disease, medications, diminished senses (taste/smell), physical limitations (reaching/bending), depression, oral issues (difficulty chewing/swallowing, mouth pain, tooth loss, poorly fit dentures), financial issues, and stress (death of a loved one) [31]. An insufficient amount of calories leads to diminished nutrients, such as vitamin C. In one study of over 400 communitydwelling elders (mean age of 76.8) with varying diets, the average intake of vitamin $\mathrm{C}$ was 55.57 mg [32], which is $25.9 \%$ lower than the RDA for women and $38.3 \%$ lower than the RDA for men.

Another group of individuals who are at risk include those who are suffering from certain addictions. It has been shown that increased alcohol consumption leads to a decrease in plasma vitamin $C$ due to the action of ethanol and/or poor diet: low drinkers $(\sim 10.6 \mathrm{~g} / \mathrm{d})$ have 41.4 $\mu \mathrm{mol} / \mathrm{L}$, moderate drinkers $(\sim 59 \mathrm{~g} / \mathrm{d})$ have $32.4 \mu \mathrm{mol} / \mathrm{L}$, and alcoholics $(\sim 194.3 \mathrm{~g} / \mathrm{d})$ have 24.2 $\mu \mathrm{mol} / \mathrm{L}$ [33]. This relationship has also been shown in heroin addicts, where increased use led to a further decrease in vitamin $\mathrm{C}$ levels [34]. In another study, various drug addicts were shown to have a $43.6 \%$ lower vitamin $C$ level than control subjects [35].

Women who are pregnant are also at risk for vitamin $\mathrm{C}$ deficiency, due to increased oxidative stress [36]. Pregnant women who are obese (BMI $>30 \mathrm{~kg} \mathrm{~m}-2)$ have a greater risk of low vitamin $\mathrm{C}$ levels than pregnant women of a healthy weight (BMI 18-25 kg m-2), because their oxidative stress has been shown to be greater [37]. Low vitamin C levels during pregnancy can lead to various health issues to the fetus, such as low birth weight [36]. Many women take iron supplements during pregnancy, and it has been shown to decrease vitamin $\mathrm{C}$ levels. In one study, pregnant women who were taking iron supplements showed a $24 \%$ decrease in vitamin C levels from the $1^{\text {st }}$ to the $3^{\text {rd }}$ trimester, while women who were not taking iron supplements only showed a $3.7 \%$ loss [38]. 
Individuals who are being treated in hospitals may also suffer from vitamin $\mathrm{C}$ deficiency. This is especially true for maintenance haemodialysis (MHD) patients. One study determined that $44.1 \%$ of MHD patients are vitamin C deficient with $<2 \mu \mathrm{g} / \mathrm{mL}$ (or $<11 \mu \mathrm{mol} / \mathrm{L}$ ) [39]. This is due to multiple factors, one being that MHD patients need to avoid foods that are high in potassium in order to help prevent hyperkalemia. Potassium-rich foods tend to be high in vitamin $\mathrm{C}$; therefore, a decrease in potassium also causes a decrease in vitamin C [39]. Another reason these patients are at risk is that each dialysis treatment they receive can remove an average of $66 \mathrm{mg}$ of vitamin C from their plasma levels [40].

\section{VITAMIN C DEFICIENCY - SYMPTOMS:}

A person who has a normal intake of vitamin $\mathrm{C}$ will have plasma levels of $>28 \mu \mathrm{mol} / \mathrm{L}$ or $0.4-0.9$ $9 \mathrm{mg} / \mathrm{dl}$ [41-42]. An individual with depleted vitamin C will have plasma levels between 11-28 $\mu \mathrm{mol} / \mathrm{L}$ or $0.2-0.39 \mathrm{mg} / \mathrm{dl}$ [41-42]. In order for an individual to be deficient, their vitamin $\mathrm{C}$ plasma levels must be $<11 \mu \mathrm{mol} / \mathrm{L}$ or $<0.2 \mathrm{mg} / \mathrm{dl}$ [41-42]. Though the human body is resilient, vitamin $\mathrm{C}$ is an essential and water-soluble nutrient that is quickly excreted. Vitamin $\mathrm{C}$ has a half-life of 16 days in our bloodstream and, if ingestion of it stops completely, it will be eliminated within 35-40 days [43]. Blood plasma levels drop fairly quickly; however, the symptoms of deficiency take much longer to develop [44]. In order to prevent deficiency, humans must ingest $10 \mathrm{mg}$ of vitamin $\mathrm{C}$ daily (this prevents deficiency; but, does not provide enough to reach normal plasma levels) [45]. One of the earliest symptoms is, unfortunately, very non-specific: fatigue. This is due to the fact that vitamin $\mathrm{C}$ is involved in the biosynthesis of carnitine, a compound essential for producing energy by transporting long-chain fatty acids into the mitochondria [46]. A plethora of symptoms in vitamin C deficiency are related to collagen, an essential element in tendon, cartilage, bone and skin function [47]. Vitamin C is required by proline hydroxylase and lysine hydroxylase (enzymes in procollagen biosynthesis), and a deficiency leads to unstable collagenous structures [46, 48]. This causes tooth loss, joint pain, bone and connective tissue disorders, poor wound healing and, more specifically: bleeding, bruising, edema, hemorrhage, gingivitis, and corkscrew hairs [48-50].

\section{VITAMIN C OVERDOSE - EFFECTS:}

The side effects of normal vitamin $\mathrm{C}$ intake are very minor, if non-existent, due to the fact that it is water soluble and quickly excreted [51]. There have been some reports of negative effects in larger doses, and to help prevent that, the USDA set the upper tolerable limit (UL) for vitamin C at $2 \mathrm{~g}$ [23]. Gastrointestinal distress and diarrhea are the most common side effects, which have been shown in single oral doses of 5-10 $\mathrm{g}$ or greater than $2 \mathrm{~g}$ daily, with symptoms disappearing within 1-2 weeks [51-52]. There has been evidence to suggest a few more severe side effects with high-dose vitamin C. The most note-worthy is the production of calcium oxalate stones in patients with renal issues (though some healthy individuals can also produce excessive oxalate at doses greater than $1 \mathrm{~g}$ daily [53]). This is because vitamin $\mathrm{C}$ converts to oxalate during the elimination process, which can cause formation of stones at high doses. In a fairly recent study there was evidence to support limited, but still statistically significant, oxalate formation with high dose vitamin C. Both groups took an oral $1 \mathrm{~g}$ vitamin $\mathrm{C}$ supplement twice daily for 6 days ( 2 trials were completed); the healthy group reported a $20 \%$ increase in oxalate, while the group 
with renal issues had a 33\% increase [54]. This study helps to explain the controversy between whether high dose vitamin $\mathrm{C}$ is dangerous or not. There are documented cases of oxalate stone formation in subjects with renal issues; however, the incidence rate is low. A majority of the data surrounding oxalate formation provides statistically significant findings; but, not clinically significant ones [55]. An additional concern deals with an overproduction of iron. Vitamin C increases iron absorption by helping to transport iron across the epithelium in the small intestine [15]. Though this is a beneficial effect in most cases, there is potential for an iron overload in some individuals with diseases such as hemochromatosis, sideroblastic anemia, beta-thalassemia major and sickle cell anemia [56-57].

\section{OPTIMAL DAILY INTAKE:}

As with most nutrients, there are always questions about optimal intake. This can vary dramatically when considering age, health, lifestyle and gender. In terms of determining a daily amount best suited for the general population, the most recent RDA has been calculated at $90 \mathrm{mg}$ for men and $75 \mathrm{mg}$ for women, daily [23]. Many researchers believe this amount is too low, and have conducted experiments and reviews to explain why a higher daily intake would better benefit our health (Table 1).

Table 1: Comparison of optimal vitamin $\mathrm{C}$ intake

\begin{tabular}{|c|c|c|}
\hline Study/Organization & $\begin{array}{l}\text { Recommended Intake } \\
\text { (Healthy Adults) }\end{array}$ & Reasoning \\
\hline $\begin{array}{l}\text { USDA RDA } \\
(\mathrm{IOM}, \mathrm{FNB}, 2000[23])\end{array}$ & $\begin{array}{l}90 \mathrm{mg} \text { oral (men), } \\
75 \mathrm{mg} \text { oral (women) }\end{array}$ & $\begin{array}{l}\text { Meets nutrient requirements for } 97-98 \% \text { of } \\
\text { the population; calculated from an EAR }\end{array}$ \\
\hline $\begin{array}{l}\text { Vitamin C depletion-repletion } \\
\text { pharmacokinetic studies in } 7 \text { healthy } \\
\text { inpatient volunteers by using } 7 \text { doses } \\
\text { from 30-2500mg. } \\
\text { (Levine et al., } 1996 \text { [59]) }\end{array}$ & $200 \mathrm{mg}$ oral & Bioavailability was complete at $200 \mathrm{mg}$ \\
\hline $\begin{array}{l}\text { The combined evidence from human } \\
\text { metabolic, pharmacokinetic, and } \\
\text { observational studies and Phase II RCTs. } \\
\text { (Frei, Birlouez-Aragon, \& Lykkesfeldt, } \\
2012 \text { [60]) }\end{array}$ & $200 \mathrm{mg}$ oral & $\begin{array}{l}\text { Maximizes the vitamin's potential health } \\
\text { benefits with the least risk of inadequacy or } \\
\text { adverse health effects. }\end{array}$ \\
\hline $\begin{array}{l}15 \text { healthy female inpatients received in } \\
\text { succession daily vitamin C doses of } 30 \text {, } \\
60,100,200,400,1,000 \text {, and } 2,500 \mathrm{mg} \text {. } \\
\text { (Levine, Wang, Padayatty, \& Morrow, } \\
2001 \text { [58]) }\end{array}$ & $90 \mathrm{mg}$ oral (women) & $\begin{array}{l}\text { Using FNB guidelines and on the basis of } \\
\text { determination of an EAR; produces a } \\
\text { median of } \approx 80 \% \text { vitamin } C \text { saturation of } \\
\text { neutrophils; minimal urine excretion }\end{array}$ \\
\hline $\begin{array}{l}\text { Review of past findings, and analysis of } \\
\text { recent findings, on optimal vitamin C } \\
\text { dosage. (Ordman, } 2010 \text { [61]) }\end{array}$ & $500 \mathrm{mg}$ oral twice daily & $\begin{array}{l}500 \mathrm{mg} \text { of vitamin } \mathrm{C} \text { taken every } \\
12 \mathrm{hrs} \text { may reduce many major causes of } \\
\text { chronic disease, aging decline, and colds }\end{array}$ \\
\hline
\end{tabular}

In terms of gender, there is evidence to suggest that both men and women should have a RDA of $90 \mathrm{mg}$ [58]. The RDA of $90 \mathrm{mg}$ for men was calculated from depletion-repletion study data [59], and the RDA for women was calculated from the men's dose by accounting for weight 
differences (depletion-repletion study data was not available for women) [23]. Levine, Wang, Padayatty, and Morrow (2001) conducted their own depletion-repletion study specifically for women and determined that both sexes should have the same $90 \mathrm{mg}$ daily intake, based off neutrophil saturation and urinary excretion [58]. Some studies and reviews have determined that $200 \mathrm{mg}$ daily is the optimal intake [59-60], with others claiming that $1,000 \mathrm{mg}$ (500 $\mathrm{mg}$ twice daily) provides the best health effects [61]. In terms of bioavailability, the absorption efficiency of vitamin $\mathrm{C}$ is $89 \%$ for $15 \mathrm{mg} /$ day, $87 \%$ for $30 \mathrm{mg} /$ day, $85 \%$ for $50 \mathrm{mg} /$ day, $80 \%$ for 100 $\mathrm{mg} /$ day, $72 \%$ for $200 \mathrm{mg} /$ day, $63 \%$ for $500 \mathrm{mg} /$ day, and $46 \%$ for $1250 \mathrm{mg} /$ day [62]. So, although the higher intake is tolerated and absorbed to a certain extent, the maximum bioavailability seems to peak at $500 \mathrm{mg}$ [51].

Though vitamin $\mathrm{C}$ tends to be well tolerated, even with high doses, maximum limits have been established. Though the USDA has determined the UL for vitamin $\mathrm{C}$ at $2 \mathrm{~g}$ daily, the maximum tolerated single dose is $3 \mathrm{~g}$ [63], and the maximum tolerated daily dose is $18 \mathrm{~g}$ [64]. Those doses cannot be reached from food and beverage consumption; they must be administered through either oral supplementation or intravenous (IV) injection.

\section{AND ORAL SUPPLEMENTATION:}

Though vitamin $\mathrm{C}$ intake should primarily come from whole foods (to be discussed later), there are reasons to take either IV or oral supplements. Many individuals do not have access to foods high in vitamin $\mathrm{C}$ due to financial (e.g. high cost of produce) or physical (e.g. no local grocery store) limitations. Others may require more vitamin $\mathrm{C}$ due to a genetic predisposition, disease, or diet restriction [65]. Outside of trying to ensure a proper daily intake, another reason for taking supplements is for a pharmacologic effect in the treatment of diseases [65].

For individuals looking to ensure a proper daily intake of vitamin $\mathrm{C}$, oral supplementation is efficient. In the clinical setting, however, IV dosing is more regularly used. This is because IV dosing of vitamin $\mathrm{C}$ produces a much higher plasma concentration than an oral dose. It has been shown that a $3 \mathrm{~g}$ oral dose produces a peak plasma concentration of $220 \mu \mathrm{mol} / \mathrm{L}$, whereas a $3 \mathrm{~g}$ IV dose produces a peak plasma concentration of $1760 \mu \mathrm{mol} / \mathrm{L}$ [63]. IV dosing also has the potential to increase peak plasma concentrations with an increased dose, whereas oral dosing eventually reaches a plateau in peak plasma concentration [63].

\section{INCORPORATING VITAMIN C IN THE DIET:}

Vitamin $\mathrm{C}$ is a crucial element to a healthy diet, and there are a number of ways to make sure we are ingesting an adequate daily amount. Though the chemical components of vitamin $\mathrm{C}$ supplements (oral/IV) and vitamin $\mathrm{C}$ in food are identical, the benefit of ingesting natural foodbased vitamin $\mathrm{C}$ allows for the consumption of other important nutrients simultaneously [66]. This is important both for a balanced diet and for increased health effects of certain nutrients. As mentioned earlier, vitamin $\mathrm{C}$ is able to help facilitate iron absorption $[15,21]$, so consuming foods rich in those nutrients together (a spinach salad topped with strawberries) would provide a helpful effect. Another healthy combination is that of vitamin $\mathrm{C}$ and vitamin $\mathrm{E}$, as they work together to inhibit oxidation [67]. In addition, vitamin $\mathrm{C}$ can help restore vitamin $\mathrm{E}$ levels by reducing $\alpha$-tocopheroxyl (vitamin E radical) back to vitamin E [67]. Multiple studies have also shown that there is either little difference (in terms of plasma levels and urinary excretion) 
between supplemental and food-based vitamin $\mathrm{C}$, or that food-based vitamin $\mathrm{C}$ provides better absorption than supplements [68-70]. With the benefit of symbiotic nutrient relationships and similar/better reactions to that of supplements, food-based vitamin $\mathrm{C}$ may be the best choice for healthy individuals to obtain their daily requirement.

In order to ensure that individuals are getting the most vitamin $\mathrm{C}$ in their diet, there are a few items to consider. One concerns the area in which individuals live, and the availability of produce. In areas with limited produce due to the climate, individuals can attain vitamin $\mathrm{C}$ from herbs and organ meats [15]. If people live in an area without a fresh (or even frozen) produce section in their local market, they will be limited to canned fruits and vegetables, which have a much lower vitamin $\mathrm{C}$ content [5]. Even orange juice (the most frequently purchased vitamin $\mathrm{C}$ rich food [71]) tends not to be an adequate source. At 4 weeks before expiration, orange juice may only have $\sim 75 \%$ of the vitamin $\mathrm{C}$ claimed on the nutrition label, and it degrades by $\sim 2 \%$ every day after it is opened, leading to $\sim 25 \%$ at expiration [72]. In these situations, the best method would be to purchase canned fruits and vegetables that have the highest vitamin $\mathrm{C}$ content, and to choose the latest expiration date on juices rich in vitamin $\mathrm{C}$ and consume them promptly after purchasing.

Even when individuals do have access to fresh fruits and vegetables, there are many factors that can degrade vitamin $\mathrm{C}$ content. Preparation of foods is one factor that can make a huge difference. Boiling tends to degrade the vitamin $\mathrm{C}$ content of vegetables, with an average of $50.9 \%$ loss in common vegetables (table 2) [73-77]. This evidence is shown further in a recent randomized double-blind placebo control study. The 2 test groups both consumed $350 \mathrm{~g}$ of vegetables daily; group A cooked the food using specialized cookware that did not require the use of excess water, and group B cooked the food using standard methods (boiling). In just 2 weeks, the blood vitamin $\mathrm{C}$ levels in group A increased by $\sim 17 \%$, whereas group $\mathrm{B}$ only increased by $\sim 9 \%$ [78]. As shown by that study, cooking vegetables without the use of excess water can help to preserve vitamin C content. Stir frying is one method, which shows a fairly minimal 29.9\% average vitamin C loss (table 2) [73, 75-77]. Steaming foods (in a microwave or stovetop) can be a good compromise to boiling. The vitamin $\mathrm{C}$ content is preserved fairly well in steaming, with only an average $14.3 \%$ loss (Table 2 ) [73, 75-77, 79].

Table 2: Vitamin $\mathrm{C}$ loss in vegetables with different cooking methods

\begin{tabular}{|c|c|c|c|c|}
\hline Reference & Vegetable & Boiling & Stir Frying & Steaming \\
\hline $\begin{array}{l}\text { Hwang, Shin, Lee S, Lee J, \& } \\
\text { Yoo, } 2012 \text { [73] }\end{array}$ & Red Pepper & $66.5 \%$ loss & $14 \%$ loss & $34.2 \%$ loss \\
\hline $\begin{array}{l}\text { Gil, Ferreres, \&Tomás- } \\
\text { Barberán, } 1999 \text { (boiling) [74]; } \\
\text { Zeng, } 2013 \text { (steaming) [79] }\end{array}$ & Spinach & $60 \%$ loss & (no data) & $11.1 \%$ loss \\
\hline Ahmed, \& Ali, 2013 [75] & Cauliflower & $50 \%$ loss & $15 \%$ loss & $15 \%$ loss \\
\hline Xu et al., 2014 [76] & Red Cabbage & $40 \%$ loss & $62.5 \%$ loss & $6 \%$ loss \\
\hline $\begin{array}{l}\text { Yuan G, Sun, Yuan J, \& Wang, } \\
2009 \text { [77] }\end{array}$ & Broccoli & $38 \%$ loss & $28 \%$ loss & $5 \%$ loss \\
\hline Average Loss: & & $50.9 \%$ & $29.9 \%$ & $14.3 \%$ \\
\hline
\end{tabular}


Food storage is also a major factor in maintaining adequate vitamin $\mathrm{C}$ levels, and it has been established that high temperature and/or long storage periods degrade the vitamin $\mathrm{C}$ concentration of foods [80-82]. If food will not be eaten immediately after purchasing, the best method of storage (to maintain the highest level of vitamin $\mathrm{C}$ ) would be freezing. For example, baby corn loses $11.6 \%$ after 3 months $\left(0^{\circ} \mathrm{C}\right)$ [83], and broccoli and peas lose $10 \%$ after 12 months $\left(-20^{\circ} \mathrm{C}\right)[84]$.

For individuals who have access to fresh produce, the necessary amount needed to achieve the RDA of $75 \mathrm{mg}$ (women) and $90 \mathrm{mg}$ (men) [23] is not difficult to attain. As shown in table 3, some common foods (such as kiwi and red pepper) can provide more than double the RDA of vitamin $\mathrm{C}$ for men and women with just 1 cup. This is even more exaggerated in Rose hips, providing an incredible $473.3 \%$ RDA for men and $568 \%$ RDA for women (Table 3). If individuals abide by the recommendation to eat 5 servings of fruits and vegetables daily (or 400$500 \mathrm{~g}$ as determined by the World Health Organization (WHO) and the Food and Agricultural Organization of the United Nations (FAO) [85]) then their vitamin C intake would be between 210-280 mg [53]. In summary, some of the best ways to ensure proper intake are: consume fruits, vegetables and juices high in vitamin $\mathrm{C}$; choose fresh and/or frozen products over canned when available; consume fresh produce/juice within a week of purchasing; eat foods raw or cook by steaming; and store produce not intended for immediate use in freezer.

Table 3: Amount of vitamin $\mathrm{C}$ in fruits and vegetables

\begin{tabular}{|llllll|}
\hline Food & Measurement & & Vitamin C (mg) & \multicolumn{2}{l|}{ \% RDA } \\
\cline { 5 - 6 } & Serving & Weight (g) & & Men & Women \\
\hline \hline Rose hips (raw) & 1 r cup & 100 & 426 & $473.3 \%$ & $568 \%$ \\
\hline Gold kiwifruit (raw) & 1 cup, sliced & 186 & 196 & $217.8 \%$ & $261.3 \%$ \\
\hline Sweet red pepper (raw) & 1 cup, chopped & 149 & 190.4 & $211.6 \%$ & $253.9 \%$ \\
\hline Broccoli (boiled) & 1 cup, chopped & 156 & 101.2 & $112.4 \%$ & $134.9 \%$ \\
\hline Orange (raw) & 1 cup, sections & 180 & 95.8 & $106.4 \%$ & $127.7 \%$ \\
\hline Strawberries (raw) & 1 cup, halves & 152 & 89.4 & $99.3 \%$ & $119.2 \%$ \\
\hline Orange juice & 1 cup & 249 & 83.7 & $93 \%$ & $111.6 \%$ \\
\hline Grapefruit (raw) & 1 cup, sections & 230 & 79.1 & $87.9 \%$ & $105.5 \%$ \\
\hline Cherry tomatoes (raw) & 1 cup & 149 & 20.4 & $22.7 \%$ & $27.2 \%$ \\
\hline Spinach (boiled) & 1 cup & 180 & 17.6 & $19.6 \%$ & $23.5 \%$ \\
\hline Potato (baked) & 1 potato w/ skin & 148 & 14.2 & $15.8 \%$ & $18.9 \%$ \\
\hline \hline
\end{tabular}

(Modified from U.S. Department of Agriculture, Agricultural Research Service. USDA National Nutrient Database for Standard Reference Release 27 [86], \& National Nutrient Database for Standard Reference [87])

Even with the high vitamin $\mathrm{C}$ content of some foods, many individuals are still not reaching an adequate intake. One way to facilitate an increase of vitamin $\mathrm{C}$ in the diet is to supplement foods with additional vitamin $\mathrm{C}$. A review of the pros and cons of vitamin $\mathrm{C}$ enhancement in 
plants has been completed, including methods utilizing biosynthesis improvement and vitamin $\mathrm{C}$ recycling [2]. This type of genetic engineering could help communities with a limited variety of produce. For example, potatoes are a heavily consumed vegetable in both whole and processed varieties, and individuals usually have access to them in one form or another. Studies have shown 2-3 fold increases in typical vitamin $\mathrm{C}$ levels of potatoes utilizing the overexpression of genes [88-89]. With that improvement, potatoes could compete with the vitamin $\mathrm{C}$ amounts in fresh produce not available to some communities, such as grapefruit and cherry tomatoes.

\section{MANAGEMENT AND PREVENTION OF CHRONIC DISEASES WITH VITAMIN C:}

Though proper vitamin $\mathrm{C}$ intake can help keep us healthy in a general sense, there is also evidence to suggest successful clinical applications in disease prevention and management.

There are many studies which exhibit the disease management benefits of vitamin $\mathrm{C}$ on certain diseases, with a few shown in table 4. One has shown that vitamin $\mathrm{C}$ can help treat diseases that current medicines cannot, such as Epstein-Barr virus (EBV). After high dose (7.5$50 \mathrm{~g}$ ) IV vitamin $\mathrm{C}$ treatments, subjects with EBV showed a $40 \%$ decrease in early antibody (EA) immunoglobulin $\mathrm{G}$ (IgG) levels and a positive effect on disease duration (table 4) [90]. In a review on the effect of vitamin $\mathrm{C}$ on non-alcoholic fatty liver disease (NAFLD) and nonalcoholic steatohepatitis (NASH), human trials have shown that individuals afflicted with those diseases tend to have low vitamin $\mathrm{C}$ plasma concentrations and/or a low dietary intake of vitamin C [91]. This review also highlighted that treating those diseases with vitamin C (300-1000 $\mathrm{mg}$ daily) can facilitate improvement with disease symptoms (i.e. steatosis) [91]. One of those review studies by Kawanaka et.al., (2013) is highlighted in table 4 [92]. A major health issue is hypertension, and vitamin $\mathrm{C}$ has been shown to lower blood pressure. After an initial vitamin $\mathrm{C}$ dose of $2 \mathrm{~g}$, and subsequent daily doses of $500 \mathrm{mg}$ for one month, the participants' mean blood pressure dropped $9.1 \%$, providing evidence that long-term vitamin $\mathrm{C}$ treatment can reduce blood pressure in patients with hypertension (table 4) [93]. The use of vitamin $\mathrm{C}$ can also aid patients who are undergoing treatment. One study on breast cancer patients undergoing chemotherapy/radiotherapy showed that a once weekly IV dose of $7.5 \mathrm{~g}$ vitamin $\mathrm{C}$ decreased their overall side-effects (such as nausea, loss of appetite, and fatigue) by $37.5 \%$, showcasing its benefits in conjunction with standard therapies (Table 4) [94]. Another study on the use of supplemental oxygen showed that hyperoxia can cause negative side effects such as reduced coronary blood velocity (CBV) by $28 \%$, increased relative coronary resistance by $34 \%$, and decreased left ventricular (LV) systolic velocity by $11 \%$, all of which were eliminated with an IV dose of $3 \mathrm{~g}$ vitamin $\mathrm{C}$ [95].

In addition to disease management, vitamin $\mathrm{C}$ is also a good indicator of certain diseases. Low plasma levels of vitamin $\mathrm{C}$ are associated with oxidative stress, a good marker for certain diseases. As mentioned earlier, vitamin $\mathrm{C}$ helps to reduce oxidative stress in the body, such as malonyldialdehyde (MDA), which leads to an inverse correlation. Patients with chronic obstructive pulmonary disease (COPD) can have a 55.3\% higher level of MDA and a $69.4 \%$ lower level of vitamin $\mathrm{C}$ than healthy controls [96]. Patients with chronic hepatitis $\mathrm{C}$ virus (CHC) can have a $41.5 \%$ higher level of MDA and a $27.5 \%$ lower level of vitamin $\mathrm{C}$ than healthy controls [97]. Patients with chronic kidney disease (CKD) also show an inverse correlation between MDA and vitamin C, with a correlation coefficient of -0.36 [98]. Vitamin C 
plasma levels have also an inverse correlation with the incidence of heart disease, with every 20 $\mu \mathrm{mol} / \mathrm{L}$ increase in plasma yielding a $17 \%$ decrease in risk for heart failure [99].

Table 4: Disease management with vitamin C

\begin{tabular}{|c|c|c|c|c|c|c|}
\hline Study/EBM* & Analysts & $\mathbf{N}$ & Patients & Duration & Intervention & Outcome \\
\hline $\begin{array}{l}\text { A clinical study of EBV } \\
\text { infected patients at the } \\
\text { Riordan Clinic treated } \\
\text { with IV vitamin C } \\
\text { between 1997-2006, } \\
\text { compared to a } \\
\text { systematic review of } \\
\text { current vitamin C/viral } \\
\text { infection evidence. } \\
\text { (Mikirova \& } \\
\text { Hunninghake, } 2014 \\
\text { [90]) }\end{array}$ & & $\begin{array}{l}218 \text { total; } \\
35 \text { with } \\
\text { full data }\end{array}$ & $\begin{array}{l}\text { Patients } \\
\text { with } \\
\text { elevated } \\
\text { levels of } \\
\text { EBV EA } \\
\text { IgG } \\
\text { (range } 25 \\
\text { to } 211 \\
\text { AU) }\end{array}$ & $\begin{array}{l}\text { Varying } \\
\text { durations. }\end{array}$ & $\begin{array}{l}\text { IV vitamin } C \\
\text { ranging from } 7.5 \\
\text { g-50 g, } \\
\text { administered 1- } \\
20 \text { times. }\end{array}$ & $\begin{array}{l}\text { Average improvement of } \\
40 \% \text { in EBV EA IgG levels; a } \\
2.7 \% \text { improvement was seen } \\
\text { with each additional IV } \\
\text { vitamin C treatment. } \\
\text { Positive effect on disease } \\
\text { duration and reducing viral } \\
\text { antibodies. }\end{array}$ \\
\hline $\begin{array}{l}\text { A nonrandomized pilot } \\
\text { study evaluating the } \\
\text { effects of antioxidant } \\
\text { therapy on patients with } \\
\text { liver disease. } \\
\text { (Kawanaka et al., } 2013 \\
\text { [92]) }\end{array}$ & $\begin{array}{l}\text { Oral vitamin } \mathrm{C} \\
\text { and } \mathrm{E}\end{array}$ & 23 & $\begin{array}{l}\text { Patients } \\
\text { with } \\
\text { nonalcoh } \\
\text { olic } \\
\text { steatohep } \\
\text { atitis } \\
\text { (NASH) }\end{array}$ & 12 months & $\begin{array}{l}300 \mathrm{mg} / \text { day of } \\
\text { both vitamin } \mathrm{C} \\
\text { and } \mathrm{E}\end{array}$ & $\begin{array}{l}\text { Decrease of } 58.2 \% \text { serum } \\
\text { alanine aminotransferase and } \\
49.4 \% \text { of high-sensitivity C- } \\
\text { reactive protein } \\
\text { Combination therapy of } \\
\text { vitamins C and E minimize } \\
\text { damage and slow disease } \\
\text { progression. }\end{array}$ \\
\hline $\begin{array}{l}\text { A randomized, double- } \\
\text { blind, placebo- } \\
\text { controlled study } \\
\text { evaluating the effects of } \\
\text { ascorbic acid on blood } \\
\text { pressure. (Duffy et al., } \\
1999 \text { [93]) }\end{array}$ & Oral vitamin $\mathrm{C}$ & $\begin{array}{l}45 \\
\text { initial; } \\
39 \text { final }\end{array}$ & $\begin{array}{l}\text { Patients } \\
\text { with } \\
\text { hypertens } \\
\text { ion }\end{array}$ & 1 month & $\begin{array}{l}\text { One initial } 2 \mathrm{~g} \\
\text { dose, then } 500 \\
\mathrm{mg} / \text { day for } 30 \\
\text { days }\end{array}$ & $\begin{array}{l}\text { Decrease in systolic blood } \\
\text { pressure }(8.4 \%) \text { and mean } \\
\text { blood pressure }(9.1 \%) \\
\text { Long-term vitamin C } \\
\text { treatment reduces blood } \\
\text { pressure in patients with } \\
\text { hypertension. }\end{array}$ \\
\hline $\begin{array}{l}\text { An epidemiological, } \\
\text { retrospective cohort } \\
\text { study with parallel } \\
\text { groups evaluating the } \\
\text { safety and efficacy of } \\
\text { vitamin C for breast } \\
\text { cancer patients. } \\
\text { (Vollbracht et al., } 2011 \\
\text { [94]) }\end{array}$ & $\begin{array}{l}\text { IV vitamin C- } \\
\text { Injektopas }{ }^{\circledR /} \\
\text { Pascorbin }{ }^{\circledR}\end{array}$ & 125 & $\begin{array}{l}\text { Patients } \\
\text { with } \\
\text { breast } \\
\text { cancer in } \\
\text { their first } \\
\text { postopera } \\
\text { tive year }\end{array}$ & 12 months & $\begin{array}{l}7.5 \mathrm{~g} \text { once a week } \\
\text { for } 4 \text { weeks } \\
\text { during adjuvant } \\
\text { therapies (not } \\
\text { administered on } \\
\text { the days of } \\
\text { chemo- and } \\
\text { radiotherapy). }\end{array}$ & $\begin{array}{l}37.5 \% \text { reduction in } \\
\text { complaints from side-effects } \\
\text { during therapy and } 52.5 \% \\
\text { reduction during aftercare } \\
\text { compared to control } \\
\text { IV vitamin C optimizes } \\
\text { standard tumor-destructive } \\
\text { therapies and reduces quality } \\
\text { of life-related side-effects. }\end{array}$ \\
\hline
\end{tabular}

*Evidence-based medicine

There are quite a few ways in which vitamin $\mathrm{C}$ can be used as a preventative measure, rather than a treatment. Though much of the research focuses on oral or IV routes, there is evidence to suggest important topical applications as well. A solution containing $10 \% 1$-ascorbic acid in a hydroglycolic base (water, butylene glcycol, dipropylene glycol, and ethanol), $0.5 \%$ ferulic acid and $2 \%$ phloretin has been shown to decrease the incidence of sunburned cells by $\sim 90.2 \%$, and 
DNA damage (thymine dimers) by $292.7 \%$ [100]. Topical vitamin C solutions can have protective effects against UV radiation, therefore acting as a potential prevention against certain skin cancers. Preventative effects have also been seen in diabetes, and individuals diagnosed with that disease are at risk for many complications. One of those complications involves high glucose concentrations, which activates the receptor for advanced glycation end products (RAGE) that can lead to pericyte apoptosis [101]. In a cell-culture study, ascorbate loading of $100 \mu \mathrm{M}$ was shown to completely prevent apoptosis due to RAGE activation, presenting the importance for diabetes patients to ingest enough vitamin $\mathrm{C}$ to maintain plasma concentrations of 50-100 $\mu \mathrm{M}$ [101]. Outside of the lab, evaluations of vitamin C consumption and its preventative effects on certain populations have shown some promising results. Through the third National Health and Nutrition Examination Survey, women were shown to have a 13\% lower prevalence of clinical gallbladder disease with each $27 \mu \mathrm{mol} / \mathrm{L}$ increase in their serum ascorbic acid level [102]. In an 11 year cohort study on the association of vitamin supplementation and upper gastrointestinal cancers, it was shown that multivitamin use did not help to lower risk, but specific vitamin $\mathrm{C}$ supplementation revealed a $21 \%$ lower risk of gastric noncardia adenocarcinoma (GNCA) [103]. Higher plasma levels of vitamin $\mathrm{C}$ have also been linked with a decrease in overall mortality, the greatest preventative measure. In a prospective population study, it was found that "a $20 \mu \mathrm{mol} / \mathrm{L}$ increase in plasma ascorbic acid was associated with about a $20 \%$ decline in death due to all cause, cardiovascular disease, and ischaemic heart disease" [104].

\section{CONCLUSIONS:}

Vitamin $\mathrm{C}$ is a powerful functional food ingredient with numerous health applications. Proper intake over a lifetime helps to maintain our current health and prevent future ailments. At least $10 \mathrm{mg}$ daily will prevent clinical deficiency and scurvy; but current research suggests 90-500 $\mathrm{mg}$ daily for optimal benefits. Much higher doses (many beyond the $2 \mathrm{~g} \mathrm{UL}$ ) are used in the clinical setting, with the greatest blood plasma levels achieved through IV injection. Proper doses for treatment are extremely variable, and depend upon the disease being treated. The risks of highdose vitamin $\mathrm{C}$ supplementation are almost negligible when compared to some current treatments. That being said, extremely high-doses should be administered with caution and treated as a pharmaceutical agent. In regards to disease management, continued clinical and epidemiological research will help to further understand and confirm the positive health effects from vitamin $\mathrm{C}$ in the prevention and treatment of numerous conditions. In terms of the general public, studies on the long-term effects of over-the-counter oral supplementation should be focused on, due to increasing awareness of vitamin $\mathrm{C}$ benefits. Future studies should also focus on how to safely and effectively implement vitamin $\mathrm{C}$ into diets of populations at-risk for deficiency.

List of Abbreviations: 2,2'-azinobis (3-ethylbenzothiazoline-6) sulfonic acid, ABTS; chloramphenicol acetyltransferase, CAT; chronic hepatitis $\mathrm{C}$ virus, $\mathrm{CHC}$; chronic kidney disease, CKD; chronic obstructive pulmonary disease, COPD; coronary blood velocity, CBV; dehydroascorbic acid, DHA; early antibody, EA; Epstein-Barr virus, EBV; estimated average 
requirement, EAR; Food and Agricultural Organization of the United Nations, FAO; food and nutrition board, FNB; gastric noncardia adenocarcinoma, GNCA; glucose transporter, GLUT; gulonolactone oxidase, GLO; immunoglobulin G, IgG; institute of medicine, IOM; intravenous, IV; left ventricular, LV; low-density lipoprotein, LDL; maintenance haemodialysis, MHD; malondialdehyde, MDA; malonyldialdehyde, MDA; non-alcoholic fatty liver disease, NAFLD; non-alcoholic steatohepatitis, NASH; reactive oxygen species, ROS; receptor for advanced glycation end products, RAGE; recommended dietary allowances, RDA; sodium-dependent vitamin C transporter, SVCT; superoxide dismutase, SOD; thiobarbituric acid reactive species, TBARS; total antioxidant capacity, TAC; United States department of agriculture, USDA; upper tolerable limit, UL; World Health Organization, WHO;

Competing Interests: The authors have no financial interests or any other conflicts of interest to disclose.

Authors' Contributions: All authors contributed to this review.

\section{References:}

1. Grzybowski A, Pietrzak K: Albert Szent-Györgyi (1893-1986): the scientist who discovered vitamin C. Clinics in Dermatology 2013, 31(3):327-331.

2. Gallie DR: Increasing vitamin C content in plant foods to improve their nutritional valuesuccesses and challenges. Nutrients 2013, 5:3424-3446.

3. Mandl J, Szarka A, Bánhegyi G: Vitamin C: update on physiology and pharmacology. British Journal of Pharmacology 2009, 157:1097-1110.

4. Chatterjee IB: Evolution and the biosynthesis of ascorbic acid. Science 1973, 182:12711272.

5. Doll S, Ricou B: Severe vitamin C deficiency in a critically ill adult: a case report. European Journal of Clinical Nutrition 2013, 67:881-882.

6. Li Y, Schellhorn HE: New developments and novel therapeutic perspectives for vitamin C. J Nutr 2007, 137(10):2171-2184.

7. Tsukaguchi H, Tokui T, Mackenzie B, Berger UV, Chen XZ, Wang YX, Brubaker RF, Hediger MA: A family of mammalian Na+-dependent L-ascorbic acid transporters. Nature 1999, 399:70-5.

8. Padayatty SJ, Levine M: New insights into the physiology and pharmacology of vitamin C. CMAJ 2001, 164(3):353-355.

9. Wilson JX: Regulation of vitamin C transport. Annu Rev Nutr 2005, 25:105-125.

10. Halliwell B, Gutteridge JMC: The definition and measurement of antioxidants in biological systems. Free Radical Biology \& Medicine 1995, 18(1):125-126.

11. Young IS, Woodside JV: Antioxidants in heath and disease. J Clin Pathol 2001, 54:176186.

12. Bhandari SR, Kwak JH: Chemical composition and antioxidant activity in different tissues of brassica vegetables. Molecules 2015, 20(1):1228-1243. 
13. Kou X, Chen Q, Li X, Li M, Kan C, Chen B, Zhang Y, Xue Z: Quantitative assessment of bioactive compounds and the antioxidant activity of 15 jujube cultivars. Food Chem 2015, 173:1037-1044.

14. Martirosyan DM: Definition of functional food. Introduction to Functional Food Science. Volume 1. 2nd edition. Dallas, TX: Food Science Publisher; 2013:26.

15. Lykkesfeldt J, Michels AJ, Frei B: Vitamin C. Adv Nutr 2014, 5:16-18.

16. Tveden-Nyborg P, Johansen LK, Raida Z, Villumsen CK, Larsen JO, Lykkesfeldt J: Vitamin $C$ deficiency in early postnatal life impairs spatial memory and reduces the number of hippocampal neurons in guinea pigs. Am J Clin Nutr 2009, 90(3):540-546.

17. Smythies JR: The role of ascorbate in brain: therapeutic implications. J R Soc Med 1996, 89(5):241.

18. Padayatty SJ, Katz A, Wang Y, Eck P, Kwon O, Lee JH, Chen S, Corpe C, Dutta A, Dutta SK, Levine M: Vitamin $\mathrm{C}$ as an antioxidant: evaluation of its role in disease prevention. J Am Coll Nutr 2003, 22(1):18-35.

19. Wang Y, Russo TA, Kwon O, Chanock S, Rumsey SC, Levine M: Ascorbate recycling in human neutrophils: induction by bacteria. Proc Natl Acad Sci USA 1997, 94(25):1381613819.

20. Traber MG, Stevens JF: Vitamins C and E: beneficial effects from a mechanistic perspective. Free Radic Biol Med 2011, 51(5):1000-1013.

21. Cook JD, Reddy MB: Effect of ascorbic acid intake on nonheme-iron absorption from a complete diet. Am J Clin Nutr 2001, 73(1):93-98.

22. Ravindran RD, Vashist P, Gupta SK, Young IS, Maraini G, Camparini M, Jayanthi R, John N, Fitzpatrick KE, Chakravarthy U, Ravilla TD, Fletcher AE: Prevalence and risk factors for vitamin $\mathrm{C}$ deficiency in North and South India: a two centre population based study in people aged 60 years and over. PLoS ONE 2011, 6(12):1-8

23. Institute of Medicine. Food and Nutrition Board. Dietary Reference Intakes for Vitamin C, Vitamin E, Selenium, and Carotenoids. Washington, DC: National Academy Press; 2000.

24. Morabia A, Wynder EL: Dietary habits of smokers, people who never smoked, and exsmokers. Am J Clin Nutr 1990, 52:933-937.

25. Alberg AJ: The influence of cigarette smoking on circulating concentrations of antioxidant micronutrients. Toxicology 2002, 180(2):121-137.

26. Eiserich JP, tan der Vliet A, Handelman GJ, Halliwell B, Cross CE: Dietary antioxidants and cigarette smoke-induced biomolecular damage: a complex interaction. Am J Clin Nutr 1995, 62(6):1490S-1500S.

27. Mosdøl A, Erens B, Brunner EJ: Estimated prevalence and predictors of vitamin C deficiency within UK's low-income population. J Public Health 2008, 30(4):456-460.

28. Phipps EJ, Stites SD, Wallace SL, Braitman LE: Fresh fruit and vegetable purchases in an urban supermarket by low-income households. J Nutr Educ Behav 2013, 45(2):165170.

29. Taleghani EA, Sotoudeh G, Amini K, Araghi MH, Mohammadi B, Yeganeh HS: Comparison of antioxidant status between pilots and non-flight staff of the Army Force: pilots may need more vitamin C. Biomed Environ Sci 2014, 27(5):371-377. 
30. Rendón-Ramírez AL, Maldonado-Vega M, Quintanar-Escorza MA, Hernández G, Arévalo-Rivas BI, Zentella-Dehesa A, Calderón-Salinas JV: Effect of vitamin E and C supplementation on oxidative damage and total antioxidant capacity in lead-exposed workers. Environ Toxicol Pharmacol 2014, 37(1):45-54.

31. Sharkey JR, Branch LG, Zohoori N, Giuliani C, Busby-Whitehead J, Haines PS: Inadequate nutrient intakes among homebound elderly and their correlation with individual characteristics and health-related factors. Am J Clin Nutr 2002, 76(6):14351445.

32. Hsiao PY, Mitchell DC, Coffman DL, Allman RM, Locher JL, Sawyer P, Jensen GL, Hartman TJ: Dietary patterns and diet quality among diverse older adults: the University of Alabama at Birmingham Study of Aging. J Nutr Health Aging 2013, 17(1):19-25.

33. Lecomte E, Herbeth B, Pirollet P, Chancerelle Y, Arnaud J, Musse N, Paille F, Siest G, Artur Y: Effect of alcohol consumption on blood antioxidant nutrients and oxidative stress indicators. Am J Clin Nutr 1994, 60(2):255-261.

34. Zhou JF, Yan XF, Ruan ZR, Peng FY, Cai D, Yuan H, Sun L, Ding DY, Xu SS: Heroin abuse and nitric oxide, oxidation, peroxidation, lipoperoxidation. Biomed Environ Sci 2000, 13(2):131-139.

35. Nazrul Islam SK, Jahangir Hossain K, Ahsan M: Serum vitamin E, C and A status of the drug addicts undergoing detoxification: influence of drug habit, sexual practice and lifestyle factors. Eur J Clin Nutr 2001, 55(11):1022-1027.

36. Saker M, Soulimane Mokhtari N, Merzouk SA, Merzouk H, Belarbi B, Narce M: Oxidant and antioxidant status in mothers and their newborns according to birthweight. Eur $\mathbf{J}$ Obstet Gynecol Reprod Biol 2008, 141(2):95-99.

37. Sen S, Iyer C, Meydani SN: Obesity during pregnancy alters maternal oxidant balance and micronutrient status. Journal of Perinatology 2014, 34:105-111.

38. Anetor JI, Ajose OA, Adeleke FN, Olaniyan-Taylor GO, Fasola FA: Depressed antioxidant status in pregnant women on iron supplements: pathologic and clinical correlates. Biol Trace Elem Res 2010, 136(2):157-170.

39. Zhang K, Dong J, Cheng X, Bai W, Guo W, Wu L, Zuo L: Association between vitamin C deficiency and dialysis modalities. Nephrology (Carlton) 2012, 17(5):452-457.

40. Morena M, Cristol J-P, Bosc J-Y, Tetta C, Forret G, Leger C-L, Delcourt C, Papoz L, Descomps B, Canaud B: Convective and diffusive losses of vitamin C during haemodiafiltration session: a contributive factor to oxidative stress in haemodialysis patients. Nephrol Dial Transplant 2002, 17(3):422-427.

41. Jacob RA: Assessment of human vitamin C status. J Nutr 1990, 120(11):1480-1485.

42. Loria CM, Whelton PK, Caulfield LE, Szklo M, Klag MJ: Agreement among indicators of vitamin C status. Am J Epidemiol 1998, 147(6):587-596.

43. Noble M, Healey CS, McDougal-Chukwumah LD, Brown TM: Old disease, new look? a first report of Parkinsonism due to scurvy, and of refeeding-induced worsening of scurvy. Psychosomatics 2013, 54(3):277-283.

44. Delanghe JR, Langlois MR, De Buyzere ML, Na N, Ouyang J, Speeckaert MM, Torck MA: Vitamin C deficiency: more than just a nutritional disorder. Genes Nutr 2011, 6(4):341-346. 
45. Lindblad M, Tveden-Nyborg P, Lykkesfeldt J: Regulation of vitamin C homeostasis during deficiency. Nutrients 2013, 5:2860-2879.

46. Carr AC, Frei B: Toward a new recommended dietary allowance for vitamin $\mathrm{C}$ based on antioxidant and health effects in humans. Am J Clin Nutr 1999, 69:1086-1107.

47. Kadler KE, Baldock C, Bella J, Boot-Handford RP: Collagens at a glance. J Cell Sci 2007, 120:1955-1958.

48. Phillips CL, Yeowell HN: Vitamin C, collagen biosynthesis, and aging. In Vitamin C in Health and Disease. Edited by Packer L, Fuchs J. New York: Marcel Dekker Inc; 1997:205-230.

49. Zammit P: Vitamin C deficiency in an elderly adult. JAGS 2013, 61(4):657-658.

50. Al-Dabagh A, Milliron B-J, Strowd L, Feldman SR: A disease of the present: scurvy in “well-nourished” patients. J Am Acad Dermatol 2013, 69(5):e246-e247.

51. Fukushima R, Yamazaki E: Vitamin C requirement in surgical patients. Current Opinion in Clinical Nutrition and Metabolic Care 2010, 13(6):669-676.

52. Deruelle F, Baron B: Vitamin C: is supplementation necessary for optimal health? The Journal of Alternative and Complementary Medicine 2008, 14(10):1291-1298.

53. Levine M, Rumsey SC, Daruwala R, Park JB, Wang Y: Criteria and recommendations for vitamin C intake. JAMA 1999, 281(15):1415-1423.

54. Traxer O, Huet B, Poindexter J, Pak CY, Pearle MS: Effect of ascorbic acid consumption on urinary stone risk factors. J Urol 2003, 170(2 Pt 1):397-401.

55. Auer BL, Auer D, Rodgers AL: The effect of ascorbic acid ingestion on the biochemical and physicochemical risk factors associated with calcium oxalate kidney stone formation. Clin Chem Lab Med 1998, 36:143-148.

56. Nienhuis AW: Vitamin C and iron. N Engl J Med 1981, 304:170-171.

57. Gerster H: High-dose vitamin C: a risk for persons with high iron stores? Int J Vitam Nutr Res 1999, 69(2):67-82.

58. Levine M, Wang Y, Padayatty SJ, Morrow J: A new recommended dietary allowance of vitamin C for healthy young women. Proc Natl Acad Sci USA 2001, 98:9842-9846.

59. Levine M, Conry-Cantilena C, Wang Y, Welch RW, Washko PW, Dhariwal KR, Park JB, Lazarev A, Graumlich JF, King J, Cantilena LR: Vitamin C pharmacokinetics in healthy volunteers: evidence for a recommended dietary allowance. Proc Natl Acad Sci USA 1996, 93(8):3704-3709.

60. Frei B, Birlouez-Aragon I, Lykkesfeldt J: Authors' perspective: what is the optimum intake of vitamin C in humans? Crit Rev Food Sci Nutr 2012, 52:815-829.

61. Ordman AR: Vitamin C twice a day enhances health. Health 2010, 2(8):819-823.

62. Graumlich JF, Ludden TM, Conry-Cantilena C, Cantilena Jr LR, Wang Y, Levine M: Pharmacokinetic model of ascorbic acid in healthy male volunteers during depletion and repletion. Pharmaceutical Research 1997, 14(9):1133-1139.

63. Padayatty SJ, Sun H, Wang Y, Riordan HD, Hewitt SM, Katz A, Wesley RA, Levine M: Vitamin C pharmacokinetics: implications for oral and intravenous use. Annals of Internal Medicine 2004, 140(7):533-538.

64. Padayatty SJ, Riordan HD, Hewitt SM, Katz A, Hoffer LJ, Levine M: Intravenously administered vitamin $\mathrm{C}$ as cancer therapy: three cases. CMAJ 2006, 174(7):937-942. 
65. Zeisel SH: Is there a metabolic basis for dietary supplementation? Am J Clin Nutr 2000, 72:507S-5011S.

66. Carr AC, Vissers MCM: Synthetic or food-derived vitamin C-are they equally bioavailable? Nutrients 2013, 5(11):4284-4304.

67. Niki E, Noguchi N, Tsuchihashi H, Gotoh N: Interaction among vitamin C, vitamin E, and beta-carotene. The American Journal of Clinical Nutrition 1995, 62(6):1322S-1326S.

68. Carr AC, Bozonet SM, Vissers MC: A randomised cross-over pharmacokinetic bioavailability study of synthetic versus kiwifruit-derived vitamin C. Nutrients 2013, 5(11):4451-4461.

69. Nelson EW, Streiff RR, Cerda JJ: Comparative bioavailability of folate and vitamin C from a synthetic and a natural source. Am J Clin Nutr 1975, 28(9):1014-1019.

70. Vinson JA, Bose P: Comparative bioavailability to humans of ascorbic acid alone or in a citrus extract. Am J Clin Nutr 1988, 48(3):601-604.

71. Johnston CS, Taylor CA, Hampl JS: More Americans are eating "5 a day" but intakes of dark green and cruciferous vegetables remain low. J Nutr 2000, 130(12):3063-3067.

72. Johnston CS, Bowling DL: Stability of ascorbic acid in commercially available orange juices. Journal of the American Dietetic Association 2002, 102(4):525-529.

73. Hwang IG, Shin YJ, Lee S, Lee J, Yoo SM: Effects of different cooking methods on the antioxidant properties of red pepper (Capsicum annuum L.). Prev Nutr Food Sci 2012, 17(4):286-292.

74. Gil MI, Ferreres F, Tomás-Barberán FA: Effect of postharvest storage and processing on the antioxidant constituents (flavonoids and vitamin C) of fresh-cut spinach. J Agric Food Chem 1999, 47(6):2213-2217.

75. Ahmed FA, Ali RFM: Bioactive compounds and antioxidant activity of fresh and processed white cauliflower. Biomed Res Int 2013, 2013:1-9.

76. Xu F, Zheng Y, Yang Z, Cao S, Shao X, Wang H: Domestic cooking methods affect the nutritional quality of red cabbage. Food Chemistry 2014, 161:162-167.

77. Yuan G, Sun B, Yuan J, Wang Q: Effects of different cooking methods on healthpromoting compounds of broccoli. J Zhejiang Univ Sci B 2009, 10(8):580-588.

78. Mori M, Hamada A, Mori H, Yamori Y, Tsuda K: Effects of cooking using multi-ply cookware on absorption of potassium and vitamins: a randomized double-blind placebo control study. Int J Food Sci Nutr 2012, 63(5):530-536.

79. Zeng C: Effects of different cooking methods on the vitamin C content of selected vegetables. Nutrition \& Food Science 2013, 43(5):438-443.

80. Chaudhary PR, Jayaprakasha GK, Porat R, Patil BS: Low temperature conditioning reduces chilling injury while maintaining quality and certain bioactive compounds of 'Star Ruby' grapefruit. Food Chem 2014, 153:243-249.

81. Fan X, Sokorai KJ: Changes in quality, liking, and purchase intent of irradiated fresh-cut spinach during storage. J Food Sci 2011, 76(6):S363-S368.

82. Robles-Sánchez RM, Islas-Osuna MA, Astiazarán-García H, Vázquez-Ortiz FA, MartínBelloso O, Gorinstein S, González-Aguilar GA: Quality index, consumer acceptability, bioactive compounds, and antioxidant activity of fresh-cut "ataulfo" mangoes (mangifera indica L.) as affected by low-temperature storage. J Food Sci 2009, 74(3):S126-S134. 
83. Hooda S, Kawatra A: Effect of frozen storage on nutritional composition of baby corn. Nutrition \& Food Science 2012, 42(1):5-11.

84. Favell DJ: A comparison of the vitamin $\mathrm{C}$ content of fresh and frozen vegetables. Food Chemistry 1998, 62(1):59-64.

85. World Health Organization: Diet, Nutrition and the Prevention of Chronic Diseases. Report of a Joint WHO/FAO Expert Consultation. WHO Technical Report Series no. 916. Geneva: WHO; 2003.

86. U.S. Department of Agriculture, Agricultural Research Service. USDA National Nutrient Database for Standard Reference, Release 27. [http://www.ars.usda.gov/ba/bhnrc/ndl]

87. National Nutrient Database for Standard Reference [http://ndb.nal.usda.gov/ndb/foods/show/8256?fg=\&man=\&lfacet=\&count=\&max=\&sort $=\& q$ lookup $=\&$ offset $=\&$ format $=$ Full $\&$ new $=\&$ measureby $=]$

88. Bulley S, Wright M, Rommens C, Yan H, Rassam M, Lin-Wang K, Andre C, Brewster D, Karunairetnam S, Allan AC, Laing WA: Enhancing ascorbate in fruits and tubers through over-expression of the L-galactose pathway gene GDP-L-galactose phosphorylase. Plant Biotechnol J 2012, 10(4):390-397.

89. Hemavathia, Upadhyayaa CP, Younga KE, Akulaa N, Kimb HS, Heungb JJ, Ohc OM, Aswathd CR, Chuna SC, Kima DH, Parka SW: Over-expression of strawberry dgalacturonic acid reductase in potato leads to accumulation of vitamin $\mathrm{C}$ with enhanced abiotic stress tolerance. Plant Science 2009, 177(6):659-667.

90. Mikirova NA, Hunninghake R: Effect of high dose vitamin C on Epstein-Barr viral infection. Med Sci Monit 2014, 20:725-732.

91. Ipsen DH, Tveden-Nyborg P, Lykkesfeldt J: Does vitamin C deficiency promote fatty liver disease development? Nutrients 2014, 6:5473-5499.

92. Kawanaka M, Nishino K, Nakamura J, Suehiro M, Goto D, Urata N, Oka T, Kawamoto H, Nakamura H, Yodoi J, Hino K, Yamada G: Treatment of nonalcoholic steatohepatitis with vitamins $\mathrm{E}$ and $\mathrm{C}$ : a pilot study. Hepat Med 2013, 5:11-16.

93. Duffy SJ, Gokce N, Holbrook M, Huang A, Frei B, Keaney Jr JF, Vita JA: Treatment of hypertension with ascorbic acid. The Lancet (North American Edition) 1999, 354(9195):2048-2049.

94. Vollbracht C, Schneider B, Leendert V, Weiss G, Auerbach L, Beuth J: Intravenous vitamin $\mathrm{C}$ administration improves quality of life in breast cancer patients during chemo/radiotherapy and aftercare: results of a retrospective, multicentre, epidemiological cohort study in Germany. In Vivo 2011, 25(6):983-990.

95. Gao Z, Spilk S, Momen A, Muller MD, Leuenberger UA, Sinoway L: Vitamin C prevents hyperoxia-mediated coronary vasoconstriction and impairment of myocardial function in healthy subjects. Eur J Appl Physiol 2012, 112(2):483-492.

96. Cristóvão C, Cristóvão L, Nogueira F, Bicho M: Evaluation of the oxidant and antioxidant balance in the pathogenesis of chronic obstructive pulmonary disease. Rev Port Pneumol 2013, 19(2):70-75. 
97. El-Kannishy G, Arafa M, Abdelaal I, Elarman M, El-Mahdy R: Persistent oxidative stress in patients with chronic active hepatitis-C infection after antiviral therapy failure. Saudi J Gastroenterol 2012, 18(6):375-379.

98. Takahashi N, Morimoto S, Okigaki M, Seo M, Someya K, Morita T, Matsubara H, Sugiura T, Iwasaka T: Decreased plasma level of vitamin C in chronic kidney disease: comparison between diabetic and non-diabetic patients. Nephrol Dial Transplant 2011, 26(4):1252-1257.

99. Pfister R, Sharp SJ, Luben R, Wareham NJ, Khaw KT: Plasma vitamin C predicts incident heart failure in men and women in European Prospective Investigation into Cancer and Nutrition-Norfolk prospective study. Am Heart J 2011, 162(2):246-253.

100. Oresajo C, Stephens T, Hino PD, Law RM, Yatskayer M, Foltis P, Pillai S, Pinnell SR: Protective effects of a topical antioxidant mixture containing vitamin $\mathrm{C}$, ferulic acid, and phloretin against ultraviolet-induced photodamage in human skin. J Cosmet Dermatol 2008, 7(4):290-297.

101. May JM, Jayagopal A, Qu ZC, Parker WH: Ascorbic acid prevents high glucose-induced apoptosis in human brain pericytes. Biochem Biophys Res Commun 2014, 452(1):112117.

102. Simon JA, Hudes ES: Serum ascorbic acid and gallbladder disease prevalence among US adults: the third National Health and Nutrition Examination Survey (NHANES III). Arch Intern Med 2000, 160(7):931-936.

103. Dawsey SP, Hollenbeck A, Schatzkin A, Abnet CC, Lee JE: A prospective study of vitamin and mineral supplement use and the risk of upper gastrointestinal cancers. PLoS One 2014, 9(2):e88774.

104. Khaw K-T, Bingham S, Welch A, Luben R, Wareham N, Oakes S, Day N: Relation between plasma ascorbic acid and mortality in men and women in EPIC-Norfolk prospective study: a prospective population study. The Lancet (British edition) 2001, 357(9257):657-663. 